\title{
STUDI EVALUATIF UJI COBA PENAYANGAN PROGRAM TELEVISI/VIDEO PEMBELAJARAN TENTANG "TINGKAH LAKU PUBERTAS"
}

Oleh: Waldopo*

\section{Abstrak}

Anak memasuki usia remaja sangat membutuhkan informasi yang berkaitan dengan perubahan-perubahan yang akan yang sedang terjadi pada dirinya (perubahan fisik maupun perubahan psikis) yang mana hal ini kadang-kadang tidak atau kurang disadari oleh para orang tua. Kesimpulan ini merupakan salah satu temuan penting dari hasil ujicoba penayangan program Televisi/Video Pendidikan yang berjudul "Tingkah Laku Pubertas". Dari 160 siswa kelas III SLTP yang menjadi responden, lebih dari 90\% menyatakan bahwa mereka baru menyadari tentang adanya perubahan-perubahan yang terjadi pada dirinya, baik perubahan yang bersifat fisik maupun psikis setelah menyaksikan tayangan program. Padahal informasi yang demikian seharusnya jauh-jauh hari sudah diinformasikan oleh para orang tua kepada putra-putrinya. "Tingkah Laku Pubertas" merupakan salah satu program video/televisi pendidikan tentang Pemasyarakatan IImu Pengetahuan dan Teknologi produksi kerja sama antara Pusat Teknologi Komunikasi dan Informasi Pendidikan (PUSTEKKOM DEPDIKNAS) dengan SEAMEO-RECSAM (Organisasi Menteri Pendidikan negara-negara Asia Tenggara di bidang sains dan matematika). Program yang berdurasi sekitar 25 menit ini merupakan program video/televisi pendidikan dengan sasaran anak-anak menjelang usia remaja (siswa SLTP Kelas III atau SLTA kelas I).

*) Drs. Waldopo, M.Pd. adalah Staf Teknis pada Sub Bidang Evaluasi Sistem PUSTEKKOM, DEPDIKNAS 


\section{Kata-kata Kunci:}

Edutainment.

Instructional Television (ITV).

SEAMEO-RECSAM.

Prime source of news.

\section{PENDAHULUAN}

Salah satu missi SEAMEO-RECSAM (Organisasi Menteri-menteri Pendidikan se Asia Tenggara yang menangani bidang Sains dan Matematika) adalah memasyarakatkan sains dan matematika kepada masyarakat (khususnya masyarakat yang tinggal di negara-negara Asia Tenggara). Misi ini erat kaitannya dengan misi Pusat Teknologi Komunikasi dan Informasi Pendidikan (PUSTEKKOM)-Departemen Pendidikan Nasional, yakni ikut menyukseskan program pemerataan, peningkatan mutu dan penyelenggaraan pendidikan yang efektif dan efisien dengan memanfaatkan berbagai sumber belajar serta perkembangan ilmu pengetahuan dan teknologi secara maksimal.

Seiring dengan kesamaan misi dari kedua lembaga tersebut, maka dirintislah suatu kerja sama di antara keduanya untuk memproduksi program-program televisi/video pembelajaran yang bertujuan untuk memasyarakatkan ilmu pengetahuan dan teknologi kepada masyarakat di samping penyediaan sumber belajar yang dapat dimanfaatkan untuk kepentingan pemerataan serta peningkatan mutu pendidikan.

Kerjasama ini telah dimulai sejak tahun anggaran 1998/1999. Selama dua tahun telah diproduksi beberapa judul program televisi pembelajaran dalam bidang studi Fisika, Biologi, dan Matematika. Program-program tersebut berisikan materi pengayaan dengan sasaran siswa-siswa Sekolah Dasar (SD) dan Sekolah Lanjutan Tingkat Pertama (SLTP). Program ini nantinya diharapkan dapat dimanfaatkan oleh siswa-siswa Sekolah Dasar (SD) dan Sekolah 
Lanjutan Tingkat Pertama (SLTP) pada umumnya dan siswa-siswa di negara-negara Asia Tenggara khususnya.

Meskipun program-program tersebut telah dikembangkan sedemikian rupa dengan melibatkan para pakar, baik dalam bidang materi maupun media, serta para guru sehingga diyakini dapat dimanfaatkan dengan sebaik-baiknya oleh siswa-siswa SLTP sebagai sarana untuk memperkaya pengetahuan/ketrampilan mereka, namun masih diperlukan suatu langkah untuk di tempuh, yaitu uji coba lapangan. Kegiatan ini bertujuan untuk mengetahui seberapa jauh manfaat program TV pembelajaran (mudah/tidaknya program tersebut dipahami siswa) sehingga bermanfaat dalam meningkatkan pengetahuan dan ketrampilan siswa.

Kaitannya dengan tulisan ini, penulis membatasi pada salah satu hasil ujicoba dari penayangan sebuah program televisi pembelajaran yang berjudul: "Tingkah laku Pubertas", yang berdurasi sekitar 25 menit. Sasaran program adalah siswa kelas III SLTP/SMP.

"Tingkah Laku Pubertas" merupakan program televisi/video pembelajaran berisikan informasi tentang fungsi hormon sebagai zat yang mengatur kerja alat-alat tubuh. Selain itu, secara rinci diuraikan tentang pertumbuhan dan perkembangan tubuh manusia, perubahan fisik pada masa remaja, perubahan tingkah laku pada masa remaja serta pengaruh lingkungan keluarga terhadap perubahan tingkah laku anak-anak usia remaja.

Penelitian ini bertujuan untuk memperoleh informasi tentang tingkat keterbacaan program, manfaat yang dirasakan setelah menyaksikan tayangan program serta layak tidaknya program untuk dimanfaatkan sebagai media pembelajaran.

Ada beberapa masalah yang ingin dijawab melalui penelitian/ ujicoba penayangan program ini. Masalah-masalah tersebut adalah yang berhubungan dengan: manfaat dan daya tarik program bagi 
siswa dan teman-teman seusianya, kemampuan siswa untuk menyerap pesan pembelajaran yang terdapat di dalam program, pengalaman baru yang diperoleh siswa setelah menyaksikan tayangan program dan kualitas program; terutama yang menyangkut kejelasan gambar dan suaranya, kemudahan bahasa yang digunakan untuk dimengerti, kemudahan penjelasanpenjelasannya untuk dipahami, serta bagaimana cara menyajikan materinya apakah masih dirasakan terlalu cepat atau tidak.

Masalah-masalah tersebut di atas merupakan masalah yang akan digali dari responden siswa. Sedangkan dari kalangan guru mata pelajaran sains (biologi) diharapkan dapat memberikan jawaban tentang berbagai masalah yang berhubungan dengan: efektivitas program jika digunakan sebagai media pembelajaran, kesesuaian program dengan siswa yang menjadi sasaran program, manfaat program bagi siswa, kemampuan program untuk membantu guru dalam mencapai tujuan pembelajaran, penting tidaknya materi yang dibahas di dalam program untuk diketahui siswa, minat guru untuk memanfaatkan program dalam kegiatan pembelajaran dan kualitas program (yang berhubungan dengan pemain, gambar, bahasa yang digunakan, penjelasan-penjelasannya, kejernihan narrasi, musik pendukung dan animasinya).

Hasil penelitian akan sangat berguna bagi perbaikan maupun penyempurnaan program-program video/televisi pembelajaran yang bersangkutan (khususnya) dan program-program sejenis lainnya. Selain itu, hasil penelitian ini juga akan memperkaya khasanah penelitian tentang pemanfaatan media pembelajaran khususnya yang berhubungan dengan media video/televisi pembelajaran.

\section{KAJIAN PUSTAKA}

Banyak media yang dapat dimanfaatkan sebagai sarana untuk menyampaikan materi pembelajaran kepada peserta didik, dan salah satu di antaranya adalah media televisi/video. Media ini dipilih 
dengan pertimbangan akan kemampuan/kelebihannya dalam menyajikan materi pembelajaran secara audio visual dengan jangkauan pemirsa dalam jumlah yang tidak terbatas, sehingga dalam waktu yang bersamaan tayangan program dapat ditonton oleh ribuan bahkan jutaan orang. Efektivitas program televisi mulai sangat terasa sejak diberlakukannya kebijaksanaan "Langit Terbuka" (Open Sky Policy) yang ditetapkan oleh pemerintah pada tahun 1976. Sejak saat itu, jika rumah dilengkapi dengan decoder dan parabola yang sesuai dengan spesifikasi yang diperlukan, maka tayangan program-progam televisi dapat dinikmati selama 24 jam setiap harinya.

Pertimbangan lainnya, pada saat ini televisi maupun video bukan dianggap sebagai barang mewah lagi. Keberadaan pesawat televisi sudah dianggap sebagai kebutuhan sarana untuk memperoleh hiburan, informasi serta pendidikan sehingga banyak jumlah TV yang dimiliki warga masyarakat. Dengan demikian, penayangan program-program televisi pembelajaran yang dikemas secara menarik diharapkan akan ditonton oleh warga masyarakat dalam jumlah yang besar. Pertanyaan yang perlu dijawab dari uraian ini adalah seberapa jauh kemampuan/potensi televisi dapat dimanfaatkan sebagai media pembelajaran?

\section{Hakekat Televisi Pembelajaran}

Televisi sebagai media pembelajaran dikenal dengan istilah Instructional Television (ITV). ITV merupakan bagian dari televisi pendidikan, karena pada hakekatnya untuk mencapai tujuan pendidikan sebagian besar ditempuh melalui pembelajaran. Secara singkat dapat dikatakan bahwa ITV merupakan program televisi yang didisain, dikembangkan dan dimanfaatkan untuk kepentingan pembelajaran. Penyampaian pesan (isi pembelajaran) kepada audience (sasaran program) ditempuh dengan cara menayangkannya melalui stasiun televisi.

Bosner (1977: 60) berpendapat bahwa ITV merupakan aplikasi dari berbagai metode dan teknologi pertelevisian yang 
dimanfaatkan untuk kepentingan pembelajaran. Tujuan utama dari ITV adalah untuk menyampaikan pesan pembelajaran kepada sejumlah besar audience dalam waktu yang bersamaan. Alatas (1994: 5) berpendapat bahwa ITV merupakan program televisi yang berfungsi sebagai penunjang penyelenggaraan program televisi pendidikan dan sebagai media belajar, sehingga pendekatannya dapat melalui pendekatan mengajar seperti yang dilakukan di sekolah, meskipun bisa juga dilakukan melalui pendekatan lain. Astrid Susanto (1994: 7) lebih melihat ITV dari sudut efektivitasnya. Bagi dia, yang penting dar ITV adalah kemampuannya untuk menyajikan sesuatu sehingga pesan mudah diserap oleh audience.

Dari berbagai pendapat tersebut di atas dapat disimpulkan bahwa ITV merupakan televisi yang didisain, dikembangkan dan dimanfaatkan untuk kepentingan pembelajaran.

\section{Potensi Televisi Sebagai Media Pembelajaran}

Sebagai media massa, televisi memiliki tiga fungsi utama yaitu penerangan (information), pendidikan (education), dan hiburan (entertainment). Sesuai dengan fungsinya, televisi sangat dimungkinkan untuk dimanfaatkan sebagai media pembelajaran, karena dalam berbagai hal (Brown, 1977: 347), televisi mampu memberikan rangsangan, membawa serta, memicu, membangkitkan, mempengaruhi seseorang untuk melakukan sesuatu, memberikan saran-saran, memberikan warna, mengajar, menghibur, memperkuat, menggiatkan, menyampaikan pengaruh dari orang lain, memperkenalkan berbagai identitas (ciri) sesuatu, memberikan contoh, proses internalisasi tingkah laku, berbagai bentuk partisipasi serta penyesuaian diri dan lain-lain.

Selain itu, media televisi merupakan wahana yang kuat sekali pengaruhnya dalam pembentukan pola pikir, sikap dan tingkah laku di samping menambah pengetahuan dan memperluas 
wawasan masyarakat (Harjoko, 1994:4). Widarto (1994:7) menambahkan bahwa siaran televisi memiliki daya penetrasi yang sangat kuat terhadap kehidupan manusia sehingga ia mampu merubah sikap, pendapat dan prilaku seseorang dalam rentang waktu yang relatif singkat. Dengan jangkauannya yang begitu luas, siaran televisi memiliki potensi yang luar biasa untuk dimanfaatkan semaksimal mungkin bagi kepentingan pendidikan/pembelajaran.

Pendapat yang hampir sama dikemukakan oleh Alatas (1994: 4), dengan kekuatan pandang dengarnya, siaran televisi memiliki potensi penetratif untuk mempengaruhi sikap, pandangan, gaya hidup, orientasi dan motivasi masyarakat. Secara lebih tegas, Perin (1977: 7) menyatakan bahwa televisi merupakan sumber informasi yang utama (a prime source of news). Lebih lanjut Perin menyatakan bahwa televisi memberikan pengaruh yang besar dalam kehidupan seharihari jika dibandingkan dengan media massa lainnya.

la memainkan peran utama dalam kehidupan, ia merupakan sumber informasi dan sumber belajar. Oleh karena itu, jika televisi dimanfaatkan dengan sebaik-baiknya sebagai media pembelajaran, maka televisi akan menjadi suatu media yang sangat potensial untuk menunjang tercapainya tujuan pembelajaran, karena bagi Perin, televisi dianggap sebagai media yang memiliki potensi luar biasa. la mampu memberikan motivasi, rangsangan dan dalam waktu yang bersamaan dapat dimanfaatkan oleh pemirsa dalam jumlah yang besar dari segala umur.

Secara lebih terperinci Molenda dan Russel (1982: 214) mengemukakan beberapa kelebihan televisi jika dimanfaatkan sebagai media pembelajaran. Seperti halnya film, televisi dapat mempresentasikan gambar gerak dan berwarna yang disertai suara. Media televisi dapat dipancarkan dalam jarak yang jauh, 
dapat direkam serta dapat diputar ulang kapan saja dibutuhkan.

Salomon (1977: 55) melengkapi pendapat tersebut dengan mengatakan bahwa salah satu potensi televisi jika dimanfaatkan sebagai media pembelajaran adalah kemampuannya untuk menunjukkan secara jelas dan nyata tentang proses dari suatu kejadian atau proses dari suatu perubahan.

Dari berbagai pendapat tersebut dapat disimpulkan bahwa televisi memiliki potensi yang cukup besar jika dimanfaatkan sebagai media pembelajaran. Dengan memanfaatkan televisi sebagai media pembelajaran, maka peserta didik dapat mengamati secara langsung tentang wujud benda yang sesungguhnya, mengamati proses dari suatu kejadian atau suatu perubahan, mengamati suatu gerakan dan lain-lain yang diringi dengan suara. Dengan demikian, materi (pesan) pembelajaran yang diterima oleh peserta didik tidak bersifat abstrak, tetapi menjadi kongkrit dan jelas. Oleh karena itu, sangatlah benar jika dikatakan bahwa televisi mampu memberikan motivasi, merangsang dan mendorong peserta didik untuk belajar labih jauh.

Namun demikian, Marwah Daud (1994:1) mengingatkan bahwa potensi itu hanya dapat diaktualisasikan dan dioptimalkan jika ada perencanaan dan koordinasi yang terpadu antara pemirsa, pengelola stasiun televisi, pengelola media pendidikan dan pihak pengambil keputusan. Tanpa itu, maka televisi justru akan menjadi perusak bahkan penghancur generasi yang sudah disiapkan dengan serius dan dididik melalui berbagai jenis, jenjang, dan jalur pendidikan.

Hal lainnya yang perlu mendapatkan perhatian adalah masalah daya tarik program. Karena pada hakekatnya masyarakat lebih memandang televisi sebagai media hiburan daripada media lainnya. Artinya, faktor hiburan merupakan faktor yang dominan daripada faktor lainnya (Depari, 1994: 2). Oleh karena itu, jika 
unsur hiburannya tidak diperhatikan, maka besar kemungkinan tayangan program-program televisi pembelajaran akan terasa kering dan lama-kelamaan akan ditinggalkan oleh pemirsanya (peserta didik), karena pada hakekatnya pemirsa televisi itu tidak bisa dipaksa; ia boleh menonton dan boleh juga tidak menonton.

Persoalannya barangkali bagaimana mengemas tayangan program-program televisi pembelajaran menjadi sebuah tontonan yang menghibur sekaligus berisikan informasi/pesanpesan yang perlu diketahui dan diserap oleh peserta didik. Untuk membuat program yang demikian tentu dibutuhkan keterlibatan dari berbagai pihak serta ketelitian dan kejelian dalam mengangkat tema-tema aktual yang sedang "ngetrend" sekaligus menarik, dan kemudian dikaitkan dengan pesanpesan pembelajaran yang ingin disampaikan. Meskipun secara empiris, program-program yang demikian sangat langka kita temukan, namun hendaknya hal ini tidak menjadi alasan untuk tidak memproduksi program-program televisi pembelajaran yang sekaligus menjadi tontonan sehat yang menghibur. Konsekuensi logis dari hal ini tentu diperlukan biaya yang tidak sedikit.

\section{Kelemahan Televisi sebagai Media Pembelajaran dan Cara Mengatasinya}

Meskipun para pakar telah mengakui bahwa televisi memiliki potensi yang luar biasa jika dimanfaatkan sebagai media pembelajaran, namun harus tetap kita sadari bahwa biar bagaimanapun ia tetap memiliki kelemahan. Kemudian, kita pikirkan bagaimana cara mengatasi kelemahan yang ada sehingga televisi tetap efektif jika dimanfaatkan sebagai media pembelajaran. Salah satu kelemahan yang ada menurut Molenda (1982: 214) adalah televisi sebagai media pembelajaran yang sifatnya satu arah (one way communication). Padahal dalam kegiatan pembelajaran, 
komunikasi sebaiknya dilakukan secara timbal balik (two way communication) antara peserta didik dengan sumber belajarnya.

Kelemahan tersebut di atas dapat diatasi apabila dalam kegiatan pembelajarannya, peserta didik didampingi oleh seorang guru yang berfungsi sebagai fasilitator. Melalui fasilitator inilah peserta didik dapat bertanya dan berdiskusi tentang materi pembelajaran yang baru saja mereka pelajari melalui media telvisi. Di samping itu, fasilitator juga berfungsi memberikan pengarahan serta berbagai petunjuk kepada peserta didik tentang hal-hal apa saja yang harus dilakukan/ disiapkan baik sebelum, sedang, maupun setelah mengikuti penayangan program.

Kelemahan lainnya adalah berupa biaya. Untuk menghasilkan program-program televisi pembelajaran yang menarik, enak ditonton dan sekaligus menjadi hiburan sehat tentu diperlukan keterlibatan para pakar dari berbagai disiplin. Sebagai konsekuensi dari hal ini, tentu dibutuhkan biaya yang tidak sedikit, belum lagi dengan pengadaan hardware-nya yang berupa pesawat televisi yang harganya juga relatif tidak murah. Terhadap hal ini Perin (1977: 8) berpendapat sebaliknya "There are so available and so inexpensive (where) seeing the number of consumers is large".

Jadi dari segi biaya, oleh Perin dinilai tidak mahal, karena secara teoritis dalam waktu yang bersamaan tayangan program televisi pembelajaran dapat dimanfaatkan oleh peserta didik dalam jumlah yang tidak terbatas. Apalagi bila dikaitkan dengan daya jangkaunya yang sangat luas. Di samping itu, media televisi memiliki kemampuan menyajikan materi pembelajaran dalam bentuk visual dan suara. Hal ini dinilai sangat efektif dalam kegiatan pembelajaran.

Karena dalam kenyataannya, Dwyer (1978: 1) melaporkan 
suatu hasil penelitian bahwa $94 \%$ materi pembelajaran diserap oleh peserta didik melalui indera penglihatan dan pendengarannya. Sedangkan $6 \%$ sisanya melalui indera pengecap, peraba, dan penciuman. Melihat kelebihan ini, pengadaan program yang tadinya terasa nampak mahal tadi, tentunya menjadi tidak mahal. Kelemahan lainnya menurut Molenda adalah yang berhubungan dengan kualitas tayangan program, yaitu gambar yang diterima peserta didik kualitasnya kurang bagus sebagai akibat adanya gangguan cuaca. Bila terjadi hujan lebat, mendung atau petir, maka gambar yang tampil di layar kaca biasanya kurang bagus. Hal ini tentunya akan berpengaruh pula pada hasil belajar peserta didik.

Kemajuan teknologi penayangan program televisi melalui Satelit Siaran Langsung (Direct Broadcasting Satellite) yang ada sekarang ini mampu mengatasi kelemahan tersebut. Karena secara teoritis (Republika, 1997) dan kini telah terbukti (Pen.) bahwa satelit semacam ini mampu menyajikan gambar dan suara dengan kualitas prima tanpa terpengaruh oleh kondisi cuaca maupun medan yang bergunung-gunung. Dengan demikian, segala kendala yang behubungan dengan kelemahan media televisi sebagai media pembelajaran dapat kita atasi.

\section{Kajian Penelitian yang Relevan}

Schramm (1977: 45-46) melaporkan beberapa hasil penelitian yang telah dilakukan oleh para pakar tentang pemanfaatan televisi sebagai media pembelajaran sebagai berikut:

1. Boll and Bogatz, membuat penelitian melalui sebuah eksperimen dengan mengambil sampel dari kalangan anakanak yang berasal dari empat daerah di Amerika. Anak-anak yang ditunjuk sebagai sampel penelitian dianjurkan untuk sering-sering menonton tayangan program televisi yang berjudul "Sesame Street". Setelah dalam jangka waktu tertentu, anak-anak tersebut diteliti. Hasil penelitian menunjukkan bahwa 
makin banyak menonton tayangan program "Sesame Street" makin banyak hal-hal yang dapat mereka pelajari, terutama tentang hal-hal yang berhubungan dengan angka, bentuk, pengklasifikasian (pengelompokkan), dan lain-lain.

2. Almstad and Graf, meneliti siswa-siswa kelas 10 yang mengikuti pelajaran Geometri (ilmu ukur) hanya melalui media televisi. Penelitian juga dilakukan terhadap siswa kelas 4 dan 6 yang belajar membaca melalui penggunaan media televisi.

Dua jenis pembelajaran melalui media televisi tersebut dilengkapi dengan saluran khusus yang dapat digunakan responden untuk bertanya jawab dengan guru (nara sumber) bila diperlukan. Setelah berlangsung selama 10 bulan, mereka di tes. Hasilnya menunjukkan bahwa $85 \%$ siswa-siswa kelas 10 dinyatakan lulus dalam The New York Regents Examination. Dari $85 \%$ siswa yang lulus, $30 \%$ di antaranya lulus dengan nilai di atas 90 . Hasil ini dianggap sangat memuaskan jika dibandingkan dengan hasil tes yang diperoleh dari siswa-siswa yang belajar pada kelas-kelas konvensional.

3. Herminghaus meneliti sejumlah pelajar Sekolah Menengah yang tengah mempelajari Bahasa Inggris dan IImu Pengetahuan Alam (IPA) melalui media televisi. Kegiatan pembelajaran berlangsung selama satu semester. Setelah berjalan satu semester, diadakan pengukuran dengan menggunakan dua buah tes Standar Kemampuan Berbahasa. Hasilnya menunjukkan terdapat kenaikan lebih dari $25 \%$. Sedangan untuk IImu Pengetahuan Alam (IPA) terdapat kenaikan rata-rata $60 \%$ diukur dengan menggunakan 2 buah tes Standar Kemampuan IPA.

4. Corle melakukan penelitian terhadap 32 orang guru yang dibagi dalam dua kelompok. Kelompok pertama merupakan kelompok eksperimen, di mana para guru diminta untuk selalu menonton tayangan program televisi yang berisikan tentang pengajaran 
Matematika. Kelompok kedua merupakan kelompok kontrol, mereka tidak menonton tayangan program televisi yang berisikan tentang pengajaran Matematika.

Hasil penelitian menunjukkan bahwa pada kelompok eksperimen terdapat kenaikan hasil belajar Matematika yang signifikan. Di samping itu, mereka juga mengalami kenaikan pada dua dari delapan tes prestasi mengajar, sedangkan enam tes prestasi mengajar lainnya tidak mengalami kenaikan.

5. Waldopo (1998) melakukan penelitian mengenai sikap siswasiswa SLTP terhadap tayangan program-program televisi pendidikan/pembelajaran yang disiarkan melalui stasiun Televisi Pendidikan Indonesia ditinjau dari segi tempat tinggal dan frekuensi menonton tayangan program. Responden dibagi kedalam empat kelompok, yaitu kelompok yang tinggal di daerah perkotaan dengan frekuensi menontonnya tinggi, kelompok yang tinggal di daerah perkotaan dengan frekuensi menontonnya rendah, kelompok yang tinggal di daerah pedesaan dengan frekuensi menontonnya tinggi dan kelompok yang tinggal di daerah pedesaan dengan frekuensi menontonnya rendah. Melalui uji variansi hasil penelitian menunjukkan bahwa di manapun siswa berdomisili jika frekuensi menontonnya tinggi mereka mempunyai sikap yang positif terhadap tayangan program televisi pembelajaran.

\section{METODOLOGI}

\section{Tujuan}

Penelitian ini bertujuan untuk memperoleh informasi tentang tingkat keterbacaan, manfaat yang dirasakan dan kelayakan program bagi sasaran program yaitu siswa Kelas III SLTP dan atau siswa menjelang usia pubertas terhadap program televisi/ video pemasyarakatan ilmu pengetahuan dan teknologi yang berjudul Tingkah Laku Pubertas dan Hormon pada Manusia. 
Secara lebih terperinci, ujicoba ini bertujuan untuk memperoleh informasi yang berhubungan dengan: daya tarik program, manfaat program bagi siswa dan teman-teman seusianya, bagian-bagian yang sangat disukai dan tidak disukai oleh siswa, daya serap siswa terhadap sebagian dari materi yang terdapat di dalam program, pengalaman baru yang diperoleh siswa setelah menyaksikan tayangan program, ketajaman gambargambar program sehingga dapat dilihat dengan mudah, kesederhanaan bahasa yang digunakan di dalam program sehingga dapat dimengerti, tingkat kemudahan penjelasanpenjelasannya untuk dipahami, tingkat kecepatan penyajian materinya, daya tarik para pemainnya, kejernihan narrasi (suara) di dalam program sehingga mudah dan enak didengar, dan daya tarik animasinya.

Informasi-informasi di atas akan dijaring dari siswa yang menjadi responden ujicoba. Selain itu, informasi akan dijaring dari guru mata pelajaran Biologi tentang hal-hal yang berhubungan dengan: efektif tidaknya program jika digunakan sebagai media pembelajaran, kesesuaian program dengan siswa yang menjadi sasaran program, manfaat bagi siswa, manfaat program bagi guru (khususnya dalam membantu melaksanakan tugas mengajarnya), penting tidaknya materi yang dibahas di dalam program untuk diketahui siswa, minat para guru untuk memanfaatkan program dalam kegiatan pembelajaran yang mereka laksanakan dan keinginan mereka untuk menyarankan kepada guru lain (bidang studi sejenis) agar memanfaatkan program dalam kegiatan pembelajaran.

\section{Tempat dan Waktu Penelitian}

a. Tempat (Lokasi) Penelitian

Penelitian/Uji coba dilaksanakan di 8 SLTP yang tersebar di 4 propinsi di dalam Jawa yaitu SLTP N 1 Tanjungsari, 
Sumedang - Jawa Barat, SLTP N 1 Jalan Cagak, Subang - Jawa Barat, SLTP N 4 Pakem - Yogyakarta, SLTP N 1 Bangun Tapan - Yogyakarta, SLTP N 1 Sayung, Demak Jawa Tengah, SLTP N 1 Kaliwungu, Kendal - Jawa Tengah, SLTPN 01 Buderan - Surabaya dan SLTPN 01 Sidorejo, Gresik - Jawa Timur.

b. Waktu

Penelitian/ujicoba dilaksanakan sekitar 3 bulan yakni dari bulan Januari hingga bulan Maret 2000 dengan urut-urutan kegiatan sebagai berikut:

1) Previu program yang akan diujicobakan.

2) Melakukan kajian pustaka tentang pemanfaatan program video/televisi dalam kegiatan pembelajaran.

3) Penyusunan disain.

4) Diskusi dengan ahli yang relevan untuk penyempurnaan disain.

5) Pengembangan instrumen penelitian dengan uji validitas melalui expert judgement.

6) Konfirmasi dengan daerah (lokasi yang akan dijadikan tempat penelitian) sekaligus untuk meminta ijin.

7) Pengumpulan data di lapangan.

8) Tabulasi data.

9) Analisis data.

10) Penulisan Laporan.

c. Responden

Responden dalam uji coba ini adalah siswa menjelang usia pubertas. Dari hasil diskusi dan pembicaraan dengan berbagai pihak, maka diputuskan bahwa siswa SLTP kelas III yang dianggap paling mendekati karakteristik responden yang dikehendaki. Responden dipilih secara acak dengan jumlah responden siswa untuk setiap SLTP 20 orang, sehingga secara keseluruhan ada 160 orang siswa. Usia responden berkisar antara 14 hingga 16 tahun. Jenis kelamin responden $45 \%$ nya berjenis kelamin pria dan $55 \%$ 
sisanya berjenis kelamin wanita. Berdasarkan lokasi tempat tinggalnya, 35\% responden berdomisili di dalam kota dan $65 \%$ sisanya berdomisili di pinggiran kota.

Responden lainnya adalah guru bina yang mengajarkan mata pelajaran Biologi. Setiap SLTP sedikitnya diambil 1 orang guru bina yang mengajarkan mata pelajaran tersebut. Dengan demikian, secara keseluruhan ada 8 orang responden guru bina untuk mata pelajaran Biologi.

d. Instrumen

Instrumen yang digunakan untuk mengumpulkan data adalah kuesioner untuk siswa dan guru serta pedoman observasi.

\section{e. Strategi Pengumpulan Data}

1) Responden dikumpulkan dalam satu tempat yang representatif.

2) Setelah memperoleh pengarahan dari petugas, kepada responden (siswa) dan guru diputarkan program. Selama pemutaran program, siswa dan guru diminta untuk memperhatikan program dengan seksama.

3) Petugas/peneliti mengobservasi segala reaksi dan tingkah laku siswa lainnya ketika mereka sedang belajar dengan memanfaatkan media televisi/video.

4) Setelah pemutaran program dengan dibimbing guru mata pelajaran, siswa diberikan kesempatan untuk berdiskusi atau bertanya jawab.

5) Kepada responden (siswa) dibagikan instrumen untuk memberikan penilaian terhadap program televisi yang baru saja mereka saksikan serta saran-saran perbaikannya.

6) Kepada guru mata pelajaran diminta untuk memberikan penilaian pada aspek kurikulum, materi, pembelajaran, dan aspek media serta saran-saran perbaikannya.

7) Diskusi singkat (dengar saran) antara responden 
dengan petugas.

8) Peneliti mengumpulkan instrumen yang telah diisi oleh responden untuk dianalisis.

f. Strategi Analisis Data

1) Seluruh data yang dikumpulkan dianalisis untuk diketahui bagaimana penilaian responden terhadap program-program yang baru saja mereka saksikan. Tiap aspek yang dinilai minimal harus memperoleh skor 3 (cukup). Apabila kurang dari cukup, berarti pada aspek tersebut harus diperbaiki.

2) Seluruh saran-saran perbaikan dianalisis secara deskriptif untuk bahan masukan/perbaikan bagi tim pengembang program.

g. Judul Program yang Diteliti/Diujicobakan: Tingkah Laku Pubertas (Pelajaran Sains Biologi).

\section{HASIL PENELITIAN}

1. Judul Program : Tingkah Laku Pubertas.

2. Jumlah Responden : $\mathbf{1 6 0}$ orang siswa dan $\mathbf{8}$ orang Guru Bina Mata Pelajaran Biologi

3. Temuan dari siswa :

Tentang daya tarik program, $80 \%$ siswa menyatakan program menarik, $18 \%$ nya menyatakan sangat menarik, dan hanya $2 \%$ yang menyatakan program kurang menarik. Apakah program yang baru saja ditayangkan mereka sukai. Dalam kaitan ini, $60 \%$ siswa menyatakan suka, $29 \%$ menyatakan sangat suka dan sisanya $11 \%$ yang menyatakan program kurang mereka sukai.

Terhadap pertanyaan "apakah materi pelajaran yang terdapat di dalam program dirasakan bermanfaat bagi siswa dan teman-teman 
seusia mereka", maka $73 \%$ siswa menyatakan mereka yakin bahwa materi pelajaran di dalam program bermanfaat, sedangkan $27 \%$ sisanya memberikan komentar dengan mengatakan barangkali bermanfaat.

Berkaitan dengan bagian-bagian mana saja yang disukai siswa, maka dapat dikemukakan bahwa: 56\% siswa menyukai pada bagian penjelasan tentang perubahan psikologis pada wanita, $42 \%$ menyatakan menyukai penjelasan tentang perubahan fisik pada wanita, 35\% responden menyatakan menyukai penjelasan tentang perubahan fisik dan psikologis pada laki-laki, $4 \%$ siswa menyatakan menyukai adegan seorang pelajar SLTP yang menolak ajakan temannya untuk bermain, dan $0,6 \%$ responden menyatakan senang pada narasi atau suaranya.

Sedangkan bagian-bagian yang tidak mereka sukai, dapat diperoleh jawaban bahwa: 20\% siswa menyatakan bahwa tidak ada yang tidak mereka sukai, artinya seluruh bagian yang ada di dalam program mereka sukai. Sedangkan $80 \%$ sisanya menyatakan ada yang tidak mereka sukai. Dari $80 \%$ siswa (yang menyatakan ada bagian yang tidak mereka sukai tersebut), $36 \%$ nya tidak menyukai bagian penjelasan tentang perubahan psikologis pada laki-laki, 23\%nya tidak menyukai bagian penjelasan tentang perubahan psikologis pada wanita, $20 \%$ nya tidak menyukai bagian penjelasan tentang perubahan fisik pada wanita, $15 \%$ nya tidak menyukai bagian penjelasan tentang perubahan fisik pada laki-laki, 5\%nya tidak menyukai adegan minum-minuman keras sambil main judi, dan $0,6 \%$ sisanya tidak menyukai adegan ketika bapak sedang marah-marah pada anaknya.

Kemampuan siswa untuk menjawab pertanyaan yang berhubungan dengan materi pembelajaran yang terkandung dalam program adalah sebagai berikut:

Pertanyaan materi pada Tujuan Pembelajaran Khusus pertama dapat dijawab dengan benar oleh seluruh siswa. Pertanyaan materi pada Tujuan Pembelajaran Khusus kedua, dapat dijawab dengan 
benar oleh $88 \%$ siswa dan $12 \%$ sisanya menjawab salah. Pertanyaan materi pada Tujuan Pembelajaran Khusus ketiga, dapat dijawab dengan benar oleh $82 \%$ siswa, $16 \%$ nya menjawab salah dan $2 \%$ sisanya tidak memberikan jawaban.

Terhadap pertanyaan yang menanyakan "apakah teman-teman seusia mereka perlu melihat program ini", ternyata bahwa seluruh siswa $(100 \%)$ mengatakan teman-teman seusia mereka perlu melihat program ini, karena informasi yang ada di dalam program sangat penting untuk diketahui.

Setelah menyaksikan tayangan program, apakah siswa memperoleh sesuatu yang baru (yang manfaat)? Terhadap pertanyaan ini, $90 \%$ siswa menyatakan memperoleh sesuatu yang baru, sedangkan $10 \%$ sisanya menyatakan tidak memperoleh sesuatu yang baru. Dari responden yang menyatakan memperoleh sesuatu yang baru, $84 \%$ nya menyatakan mengetahui tentang perubahan-perubahan yang terjadi pada masa pubertas (baik perubahan-perubahan yang berhubungan dengan fisik mereka maupun perubahan yang berhubungan dengan masalah psikologis); yang mana hal ini selama ini belum pernah mereka ketahui. Sedangkan $12 \%$ siswa menyatakan mengetahui hal-hal yang berhubungan dengan seluk beluk masalah pubertas dan $4 \%$ sisanya menyatakan mengetahui perubahan yang terjadi pada manusia dari kecil hingga dewasa.

Hal baru lainnya yang mereka ketahui setelah menyaksikan tayangan program adalah sebab-sebab terjadinya perubahan pada masa pubertas. Mereka mengetahui hal-hal yang akan terjadi pada masa pubertas, sehingga mereka bisa lebih mengenal dirinya dan lawan jenisnya. Kalau $90 \%$ siswa menyatakan memperoleh sesuatu yang baru (setelah menyaksikan tayangan program) seperti yang telah diuraikan di atas, maka $10 \%$ sisanya menyatakan tidak memperoleh sesuatu yang baru. Hal ini disebabkan karena mereka telah memperoleh informasi tersebut dari bahan-bahan bacaan yang mereka baca $(4,8 \%)$, penjelasan dari guru $(3 \%)$, memperoleh penjelasan dari teman mereka $(1,2 \%)$ dan $1 \%$ nya menyatakan 
telah mengetahui sendiri berdasarkan pengalaman yang terjadi pada dirinya.

Bagaimana dengan gambar-gambarnya, apakah bisa dilihat dengan jelas? Terhadap pertanyaan ini, $58 \%$ responden menyatakan gambar-gambarnya cukup jelas, bahkan $41 \%$ nya menyatakan sangat jelas dan hanya $1 \%$ siswa saja yang menyatakan gambar-gambarnya kurang jelas.

Bagaimana dengan bahasa yang digunakan, apakah dapat mereka mengerti? Terhadap pertanyaan ini, $64 \%$ siswa menyatakan semuanya dapat dimengerti, $34 \%$ nya menyatakan sebagian besar dapat dimengerti dan hanya $2 \%$ saja yang menyatakan sebagian besar tidak dapat dimengerti. Di samping itu ada satu orang responden yang mengatakan bahwa ada bahasa yang tidak ia mengerti yaitu tentang arti hormon.

Bagaimana dengan penjelasannya, apakah dapat mereka pahami? Terhadap pertanyaan ini, 53\% siswa menyatakan sebagian besar dapat memahami, 46\% menyatakan semuanya dapat mereka pahami, dan hanya ada $1 \%$ saja yang menyatakan ada penjelasan yang tidak dapat ia pahami, yaitu penjelasan tentang hormon.

Bagaimana kecepatan penyajian materinya, apakah penyajiannya dirasakan terlalu cepat? Terhadap pertanyaan ini $58 \%$ responden menyatakan sedang-sedang saja, $22 \%$ nya menyatakan terlalu cepat, dan $20 \%$ sisanya menyatakan cepat.

Tentang daya tarik pemainnya, apakah pemainnya menarik: Arti pemainnya dapat memerankan sesuai dengan peran yang dimainkan. Sekitar $56 \%$ siswa menyatakan sebagian besar pemainnya menarik, $40 \%$ nya menyatakan semua pemainnya menarik, $2 \%$ siswa menyatakan ada pemain yang tidak menarik yaitu seorang laki-laki yang mengajak seorang pelajar SLTP untuk bermain judi serta $2 \%$ sisanya menyatakan sebagian besar pemainnya tidak menarik. 
Bagaimana dengan narrasi atau suaranya, apakah suaranya cukup jernih sehingga mudah dan enak didengar? Terhadap pertanyaan ini, $42 \%$ responden menyatakan suaranya jernih, 30\% menyatakan suaranya sangat jernih, dan $28 \%$ sisanya menyatakan sedangsedang saja.

Sedangkan dari segi daya tarik gambar-gambar animasinya, sekitar $80 \%$ siswa menyatakan menarik, bahkan $16 \%$ menyatakan sangat menarik, dan $4 \%$ sisanya menyatakan sedang-sedang saja.

Beberapa saran dari siswa untuk perbaikan program adalah:

a. Agar uraian materi lebih diperdalam/diperinci (terutama tentang hormon dan alat-alat tubuh yang mengalami pertumbuhan pada masa pubertas) serta penyajiannya diperlambat. Hal ini dikemukakan oleh $60 \%$ responden.

b. Perlu diberikan penjelasan tentang cara menjaga diri agar tidak terpengaruh oleh hal-hal yang sifatnya negatif. Hal ini dikemukakan oleh $16 \%$ responden.

c. Program ini perlu dilihat oleh semua siswa agar mereka mengetahui tentang perubahan-perubahan yang terjadi pada dirinya, sehingga tidak terjerumus kepada hal-hal yang sifatnya negatif. Hal ini dikemukakan oleh $15 \%$ responden.

d. Agar dicarikan pemain yang lebih berpengalaman dan menjadi idola remaja. Hal ini dikemukakan oleh $11 \%$ responden.

e. Penjelasan tentang hormon perlu diperjelas lagi. Hal ini dikemukakan oleh $7 \%$ responden.

f. Pada akhir program perlu diberikan rangkuman. Hal ini dikemukakan oleh $5 \%$ responden.

g. Sebaiknya program ini disiarkan melalui stasiun televisi agar bisa ditonton oleh semua siswa. Hal ini dikemukakan oleh $7 \%$ responden.

h. Penjelasan tentang hal-hal yang berhubungan dengan masalah pubertas hendaknya diberikan oleh seorang dokter. Hal ini dikemukakan oleh $3 \%$ responden. 
i. Untuk pelajaran-pelajaran lain terutama yang berhubungan dengan akhlak dan agama perlu pula dibuatkan programnya. Hal ini dikemukakan oleh $7 \%$ responden.

j. Gambar-gambar yang agak porno serta adegan main kartu sambil merokok dan minum-minuman keras perlu dibuang. Hal ini dikemukakan oleh $4 \%$ responden.

k. Tulisan untuk menjelaskan gambar-gambar yang ditampilkan perlu diperbanyak. Hal ini dikemukakan oleh $6 \%$ responden.

Dari hasil observasi menunjukkan bahwa responden menyaksikan tayangan program dengan tekun dan seksama.

4. Temuan dari guru:

Temuan-temuan yang diperolrh dari 8 (delapan) orang guru yang menjadi responden ujicoba adalah sebagai berikut: Seluruh guru menyatakan bahwa program tersebut cukup efektif bila dimanfaatkan sebagai media pembelajaran, (b) sasaran programnya (siswa SLTP Kelas III) dianggap tepat atau sesuai. Jika dimanfaatkan untuk kegiatan pembelajaran, mereka yakin bahwa informasi yang terkandung di dalamnya akan sangat bermanfaat bagi siswa. Selain itu, dengan adanya program tersebut, para guru merasa terbantu dalam melaksanakan tugas mengajarnya, terutama dalam mengajarkan topik/materi yang menyangkut masalah peranan hormon, perubahan tingkah laku maupun perubahan bentuk fisik anak usia pubertas. Manfaat lainnya menurut para guru adalah bahwa anak-anak akan dapat mengamati secara langsung perubahan-perubahan yang sedang maupun yang akan terjadi pada diri mereka. Para guru juga berpendapat bahwa masalah-masalah yang dikupas dalam program sangat penting untuk diketahui siswa terutama yang menyangkut hormon dan perubahan-perubahan yang terjadi (baik fisik maupun psikis) pada masa pubertas. Karena itu seluruh guru menyatakan berminat untuk memanfaatkan program dalam kegiatan pembelajaran. Bahkan mereka akan menyarankan kepada teman-teman guru mata pelajaran sejenis untuk memanfaatkan program tersebut. 
Tentang kualitas gambar-gambarnya, 4 orang guru menyatakan bahwa gambar-gambarnya cukup jelas, bahkan 4 orang lainnya menyatakan sangat jelas. Sedangkan bahasa yang digunakan dan penjelasan-penjelasannya, seluruh guru menyatakan bahwa bahasa maupun penjelasan-penjelasannya semuanya dapat dimengerti oleh siswa.

Tentang kecepatan penyajiannya, seluruh guru menyatakan kecepatan penyajian materinya sedang-sedang saja yang berkaitan dengan daya tarik pemainnya, 6 orang guru menyatakan semua pemainnya menarik dan dua orang sisanya menyatakan sebagian besar pemainnya menarik sedangkan mengenai kejernihan suaranya, 6 orang guru menyatakan suaranya jernih, dan bahkan 2 orang sisanya menyatakan suaranya sangat jernih.

Mengenai daya tarik animasinya, 4 orang guru menyatakan menarik, 2 orang guru menyatakan sangat menarik, dan 2 orang sisanya menyatakan biasa-biasa saja. Mengenai daya dukung musiknya, 4 orang guru menyatakan musiknya mendukung, bahkan 2 lainnya menyatakan sangat mendukung, dan 2 orang sisanya menyatakan masih ragu-ragu apakah jenis musik yang digunakan mendukung atau tidak.

Saran-saran yang dikemukakan guru untuk perbaikan program adalah:

a. Agar jenis musiknya disesuaikan dengan selera anak usia pubertas.

b. Kaset program dan yang sejenisnya perlu dikirimkan ke sekolah-sekolah agar siswa-siswa lain dapat menikmati manfaatnya,

c. Materi yang ada di dalam program lebih cocok bila dimanfaatkan untuk pengayaan.

\section{KESIMPULAN DAN SARAN}




\section{Kesimpulan}

Berdasarkan uraian yang telah dikemukakan pada hasil penelitian, secara umum dapat ditarik kesimpulan bahwa program televisi/video yang berjudul Tingkah Laku Pubertas dinyatakan layak dan bisa dimanfaatkan sebagai media dalam kegiatan pembelajaran di SLTP meskipun ada hal yang perlu menjadi perhatian seperti penyajian materi yang pada umumnya masih dirasakan cepat oleh sebagian besar siswa.

Secara lebih terperinci kesimpulan dari keseluruhan program dapat dikemukakan sebagai berikut:

a. Dari Responden siswa:

1) Program menarik untuk ditonton sebagai media pembelajaran di SLTP dan dirasakan manfaatnya oleh siswa dan teman-teman seusianya.

2) Di dalam program, ada bagian-bagian yang disukai dan ada pula yang tidak disukai oleh siswa. Adegan yang sifatnya negatif seperti mabuk-mabukan dan mengajak membolos sekolah umumnya tidak disukai. Sebaliknya adegan yang sifatnya positif seperti rajin belajar, membantu orang tua, dan lain-lain umunya disukai siswa.

3) Daya serap siswa terhadap sebagian materi pembelajaran yang terdapat dalam program di nilai pada umumnya bagus, lebih dari $80 \%$ responden bisa menjawab dengan benar atas pertanyaan-pertanyaan yang menyangkut materi pembelajaran.

4) Setelah menyaksikan tayangan program, siswa merasa memperoleh pengalaman baru dalam hal penambahan pengetahuan, dan pengalaman.

5) Gambar-gambar yang terdapat dalam program tersebut dapat dilihat dengan mudah/jelas.

6) Bahasa yang digunakan di dalam program dapat dimengerti.

7) Penjelasan-penjelasan materinya dapat dipahami. 
8) Speed/kecepatan penyajian materinya masih dirasa terlalu cepat.

9) Para pemain sebagian besar menarik. Artinya mereka mampu bermain sesuai dengan peran yang mereka mainkan.

10) Narrasi (suara) dalam program cukup jernih sehingga mudah dan enak di dengar.

11) Animasi yang disajikan cukup menarik. dan

12) Ada beberapa saran untuk perbaikan program (saran selengkapnya untuk setiap program dapat di lihat uraian hasil penelitian).

Dari hasil observasi menunjukkan bahwa siswa menyaksikan tayangan program dengan tekun dan seksama dari awal hingga akhir program.

b. Dari Responden Guru:

1) Program cukup effektif jika digunakan sebagai media pembelajaran.

2) Program telah sesuai dengan siswa yang menjadi sasaran program.

3) Program bermanfaat bagi siswa yang menjadi sasaran program.

4) Sasaran program yang paling tepat adalah siswa SLTP kelas III atau siswa SLTA kelas I.

5) Program bermanfaat dalam membantu guru untuk mencapai tujuan pembelajaran.

6) Materi yang dibahas di dalam program sangat penting untuk diketahui siswa.

7) Para guru berminat untuk memanfaatkan program dalam kegiatan pembelajaran, bahkan umumnya mereka ingin menyarankan kepada guru lain (bidang studi sejenis) agar memanfaatkan program dalam kegiatan pembelajaran. 
8) Gambar-gambar dalam program cukup jelas untuk dilihat.

9) Bahasa yang digunakan dalam program dapat dimengerti oleh siswa.

10) Penjelasan-penjelasannya dapat dipahami oleh siswa.

11) Penyajian materinya masih dirasakan terlalu cepat.

12) Sebagian besar pemainnya menarik.

13) Narrasi (suara) cukup jernih sehingga bisa didengar siswa dengan mudah.

14) Musiknya cukup mendukung.

15) Animasinya cukup menarik.

16) Saran perbaikan yang dikemukakan oleh guru (saran selengkapnya untuk setiap judul program dapat di lihat pada uraian Bab IV).

\section{Saran-Saran}

Berdasarkan kesimpulan-kesimpulan yang diperoleh dari hasil penelitian, dapat disampaikan beberapa saran sebagai berikut:

a. Meskipun secara umum program dianggap layak untuk dimanfaatkan sebagai media pembelajaran, namun penyajian materinya masih dirasakan terlalu cepat. Oleh karena itu, untuk produksi berikutnya penyajian materinya perlu diperlambat.

b. Ukuran huruf pada caption-caption-nya perlu diperbesar, hal ini mengingat ukuran TV monitor yang dimiliki sekolahsekolah rata-rata paling besar 20 inci.

c. Perlu ada pengulangan untuk setiap materi penting yang terdapat di dalam program. Pengulangan dapat disampaikan di akhir program atau di tempat lain yang dianggap sesuai.

d. Karena audience yang menjadi sasaran program adalah anak-anak usia remaja (pubertas), maka akan lebih baik bila salah satu pemainnya diperankan oleh tokoh yang menjadi idola mereka. 
e. Karena program dirasakan bermanfaat serta informasi yang ada dirasakan penting untuk diketahui oleh siswa yang menjadi sasaran program, maka sebaiknya program disebarkan ke sekolah-sekolah atau ditayangkan melalui stasiun televisi dengan jadwal siaran yang disebarkan ke sekolah-sekolah.

f. Program serupa perlu dikembamgkan untuk mata pelajaran lainnya.

g. Program-program yang belum diujicobakan perlu segera diujicobakan.

\section{DAFTAR KEPUSTAKAAN}

Alatas, Fahmi, "Potensi Siaran Televisi Untuk Pendidikan Sumber Daya Manusia", Makalah Bahan Seminar Lokakarya Nasional Teknologi Pendidikan Tentang : Media Massa Elektronik dan Pendidikan Sumber Daya Manusia, 1 - 3 Februari 1994 (Jakarta : IPTPI, CTPI, Pustekkom, 1994).

Bosner Paul, Instructional Television: Do We Have the Courage to

Succeed?, Englewood Cliffs, New Jersey : Educational Technology Publication, 1977.

Brown, Ray, J., Children and Television, Beverly Hills, California :

Sage Publication, Inc. 1976.

Depari, B. Eduard, "Pemenuhan Kebutuhan Pendidikan Bagi Masyarakat Melalui Media Elektronik", Makalah Bahan Seminar Lokakarya Nasional Teknologi Pendidikan Tentang : Media Massa Elektronik dan Pendidikan Sumber Daya Manusia, 1 - 3 Februari 1994 (Jakarta : IPTPI, CTPI, Pustekkom, 1994).

Dwyer, Francis M. , Strategis for Improving Visual Learning, State-

College, Pensylvania : Learning Services, 1978.

Habib, Zamris dan Waldopo, Studi Pemanfaatan Program Televisi/

Video Pembelajaran Tentang Pemasyarakatan IImu Pengetahuan dan Teknologi, Pusat Teknologi Komunikasi dan Informasi Pendidikan, Jakarta : 2000.

Hardjoko, W. Sri . "Pendayagunaan Radio dan Televisi Dalam 
Pendidikan", Makalah Bahan Seminar Lokakarya Nasional Teknologi Pendidikan Tentang : Media Massa Elektronik dan Pendidikan Sumber Daya Manusia, 1 - 3 Februari 1994 (Jakarta : IPTPI, CTPI, Pustekkom, 1994).

Heinich, Molenda, Russel, Instructional Media and The New Technologies of Instruction. New York : John Willey and Sons, 1982.

Daud, Marwah, "Pendayagunaan Radio dan Televisi", Makalah Bahan Seminar Lokakarya Nasional Teknologi Pendidikan Tentang : Media Massa Elektronik dan Pendidikan Sumber Daya Manusia, 1 - 3 Februari 1994 (Jakarta : IPTPI, CTPI, Pustekkom, 1994).

Perin, Donald G, Instructional Television : Synopsis of Television in Education, New Jersey : Educationa Technology Publication, 1977.

Schramm, Wilbur, Big Media Little Media, Tools and Technologies for Instruction, London : Sage Publication, Inc. 1977.

Solomon, Gavriel, Instructional Television : A Cognitive Approach to Media. Englewood Cliffs, New Jersey : Educationa Technology Publication, 1977.

Susanto, Astrid S. "Strategi Pendidikan Melalui Media Audio Visual", Makalah Bahan Seminar Lokakarya Nasional Teknologi Pendidikan Tentang : Media Massa Elektronik dan Pendidikan Sumber Daya Manusia, 1 - 3 Februari 1994 (Jakarta : IPTPI, CTPI, Pustekkom, 1994).

Tim Redaksi, "Dari Indostar ke Cakrawarta, Menghapus Blankspot di Tanah Air", Harian Umum Republika, tanggal 9 September 1997, p.17

Umum Republika, tanggal 25 November 1997, p.16

Waldopo, "Potensi Televisi Sebagai Media Pendidikan dan Pembelajaran", Journal Teknodik Nomor 8/IV/Teknodik/Mei/2000, Jakarta : Pustekkom Depdiknas, 2000. "Sikap Siswa SLTP Terhadap Program Televisi Pendidikan

Sekolah-TPI Berdasarkan Tempat Tinggal Siswa dan Frekuensi Menonton Tayangan Program", Journal Pendidikan dan Kebudayaan, Nomor 023 Tahun ke-6 Mei 2000, Jakarta : Badan Penelitian dan Pengembangan Departemen Pendidikan Nasional,

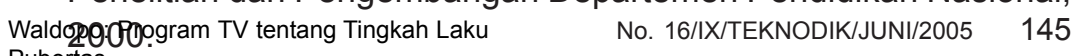
Wubertas Pendidikan Sumber Daya Manusia", Makalah Bahan Seminar Lokakarya Nasional Teknologi Pendidikan Tentang : Media Massa 